\title{
MICHEL HOUELLEBECQ E A LITERATURA COMO ESPELHO RACHADO DO ESPAÇO CONTEMPORÂNEO
} MICHEL HOUELLEBECQ AND LITERATURE AS CRACKED MIRROR OF THE CONTEMPORARY SPACE

\author{
Bruno Nunes Batista' ${ }^{1}$ (i)
}

\begin{abstract}
RESUMO
Este texto analisa a obra do escritor francês Michel Houellebecq à luz do seguinte questionamento: como esse autor contribui para a compreensão da contemporaneidade? Para tanto, a argumentação se desenvolve através de três direcionamentos: a) colocar em questão o método de trabalho de Houellebecq, descrevendo quais elementos influenciam no seu processo de escrita; b) destacar que os efeitos da acumulação flexível do capital no espaço perpassam a sua obra; c) descrever panoramicamente alguns dos seus enredos, com foco no modo através dos qual os personagens são subjetivados pelo mundo atual. Tomando por base tais objetivos, conclui-se que as transformações em curso vêm mergulhando a sociedade numa sensação de incerteza cujo resultado é um adoecimento ontológico, tratado às custas de consumismo, ansiolíticos, promiscuidade, individualismo e outros excessos. Por capturar esse contexto com maestria, sem moralismo e descompromissado de postulados teóricos, Michel Houellebecq faz da literatura uma das principais chaves de leitura do espaço contemporâneo.
\end{abstract}

Palavras-chave: Michel Houellebecq. Contemporaneidade. Literatura. Método.

\begin{abstract}
This text develops the analysis the work of the french writer Michel Houellebecq performing the following questioning: how does this author contribute to the understanding of contemporaneity? In this feeling, the argument develops through three directions: a) to question Houellebecq's work method, describing which elements influence its writing process; b) to highlight that the effects of flexible capital accumulation in the space permeate his work; c) describe some of his plots in a panoramic manner, focusing on the way in which the characters are subjectified by the current world. Through thesse goals, it is concluded that the ongoing transformations have been plunging society into a feeling of uncertainty whose result is an ontological illness, treated at the expense of consumerism, ansiolytics, promiscuity, individualism and other excesses. By capturing this context with mastery, without moralism and uncompromising theoretical postulates, Michel Houellebecq makes literature one of the main keys for reading contemporary space.
\end{abstract}

Keywords: Michel Houellebecq. Contemporaneousness. Literature. Method.

\footnotetext{
1 Universidade Federal de Pelotas- Doutor e mestre em Geografia pela Universidade Federal do Rio Grande do Sul. Bacharel em Filosofia e licenciado em Geografia. Professor da Universidade Federal de Pelotas, no Instituto de Ciências Humanas.

Autor Correspondente: Bruno Nunes Batista

E-mail: brunonunes.86@hotmail.com
}

Recebido em 18 de Fevereiro de 2021 | Aceito em 30 de Agosto de 2021. 


\section{Um escritor maldito, mas necessário}

Leveza, rapidez, exatidão, visibilidade e multiplicidade. No planejamento das cinco conferências na Universidade de Harvard no ano letivo de 1985-1986, Italo Calvino elencou essas características como fundamentais para a literatura do século XXI. E quem senão o francês Michel Houellebecq, um dos escritores mais populares na Europa, traduzido em mais de quarenta países e tendo ultrapassado a marca de três milhões de exemplares vendidos, para atender a essas qualidades? Nascido na Ilha da Reunião em 1958, diplomado em Agronomia e alçado ao sucesso com Partículas elementares, as razões da popularidade da obra de Houllebecq se aproximam dos elementos aventados em tais conferências.

Com leveza, esse autor conta sobre personagens que tentam, desesperadamente, livrarem-se do peso do mundo às custas de humor e sarcasmo; valem-se de clássicos da arte, do cinema e da filosofia para contornar uma realidade agressiva, burocrática e enfadonhamente previsível.

As histórias são construídas com extraordinária rapidez. Nos termos de Calvino (1990), isso significa uma economia de narrativa em que os acontecimentos são interligados por um segmento retilíneo, avançando ininterruptamente até um desfecho que, amiúde, acaba mal. Houllebecq divaga, tergiversa e elucubra, mas o faz a fim de avançar seus objetivos. Frases pomposas, exercícios desnecessários de erudição e outros recursos que poderiam truncar o desenvolvimento não são encontrados.

O enredo é fluído, claro e se desenrola de um modo brutalmente objetivo. Em outras palavras, tem exatidão. Na retaguarda de cada livro de Houllebecq está colocado um projeto definido, calculado em detalhes e que faz uso de uma linguagem preciosa, que introduz o leitor de forma hábil no universo daqueles personagens. Frases curtas e bem dosadas, a simplicidade com que Houllebecq escreve chega até mesmo a parecer fácil de ser reproduzida. Ledo engano: reside nela uma escrita cuidadosa com nuances e detalhes, de forma que não raro nos sentimos dentro daqueles ambientes, cúmplices de problemas que se aproximam daqueles que vivenciamos diariamente.
Tais descrições nos levam à questão da visibilidade. Houllebecq compõe um imaginário tecido do movimento duplo do texto à imagem, da imagem ao texto. $O$ resultado é a imersão daquele que lê numa rede de significantes e significantes, com os cenários sendo, simultaneamente, teatrais e transparentes. Teatrais: uma polissemia de sentidos que vai depender daquele que lê. Transparentes: não há nada a esconder, tudo está claro e é dolorosamente real, e se não havíamos visto, é porque não queríamos. Por outro lado, a imaginação propagada funciona como um "repertório do potencial, do hipotético, de tudo quanto não é, nem foi e talvez não seja, mas que poderia ter sido" (Calvino, 1990, p. 106). E quiçá o seja. Possibilita-nos assim uma pedagogia para si mesmo, estimulando o exercício de se concentrar na leitura, "fechar os olhos" e contemplar um mundo fantástico - e verdadeiro.

Também da multiplicidade empreendida por Italo Calvino parece Michel Houllebecq dar conta. Essa noção pode ser entendida como a literatura que opera com "sistemas de sistemas", o que significa tecer uma rede de conexões entre os fatos, as pessoas e o mundo; tais elementos se condicionam reciprocamente, os efeitos agem sobre as causas, percorrendo um anel retroativo que não cessa de ser retroalimentado. Uma multiplicação de detalhes que criam personagens complexos e com identidades impossíveis de serem enquadradas. São sujeitos que existem e se fazem em situação. Poderiam ser compreendidos como produtos da terceira revolução industrial, do processo de globalização e do neoliberalismo. Mas jamais seriam considerados passivos ou meras tábulas rasas: nascidos em meio às transformações culturais pós-1968, são agentes históricos, fomentando uma liberdade esquizofrênica que não sabe para onde ir e, enquanto o vai, deixa rastros de destruição pelo caminho.

Apenas por esses motivos a relevância da obra de Houllebecq para a contemporaneidade já estaria dada. Trata-se de um escritor completo, dotado de técnica invejável e com um repertório interdisciplinar de largo alcance. Não é mero acaso o seu sucesso. No entanto, para além dos aspectos estilísticos e dos recursos ficcionais, há algo a mais que gostaria de pleitear: o argumento de que seus livros podem ser 
considerados como capturas em texto das inúmeras transformações em curso na Pós-Modernidade. Para tanto, ao discutir o que está em jogo nas narrativas houellebecquianas, é preciso destacar uma questão de método. E que teria como correia de transmissão os efeitos do capitalismo tardio na combinação espaço-tempo atual, com dramáticos impactos ontológicos.

Com o foco nesses elementos, estarei pleiteando um lugar ao lado daqueles que compreendem as artes literárias como chave de leitura do mundo; opondo-me, consequentemente, à ideia de que possa haver uma separação hierárquica entre ciência e literatura.

\section{Questão de método}

Certamente não o único, mas seguramente um dos mais importantes, Platão contribuiu para a noção de que as artes seriam saberes marginais, desimportantes e descartáveis. Um exemplo é $A$ república, onde aparece a famosa Alegoria da Caverna, uma das narrativas fundadoras do pensamento ocidental. $E$ na qual o filósofo opera com a mímeses. Esse termo pode ser traduzido como imitação, ou ato de imitar. Também se refere à representação, em que colocamos uma codificação no lugar da coisa em si. Pode ser também definido como ação de reproduzir, de figurar.

A partir dessa etimologia, um segundo passo para entender a mímeses sob o ângulo de Platão é relembrar a Doutrina dos Dois Mundos aventada no mito em tela, em que foram prospectados dualismos como aparência e essência, doxa e episteme, sensibilidade e inteligibilidade, opinião e conhecimento. Nessa linha de raciocínio, a tarefa do pensamento é alcançar por intermédio do processo educacional-filosófico-metafísico a verdade. Para alcançá-la, compete ao sujeito colocar-se na linha de irradiação do sol. A saída da caverna é uma espécie de purificação, em que a luz possibilita ver as ideias puras, até então obliteradas pelas trevas e pela cegueira da corporeidade. Platão traça uma linha dividida em que o mundo sensível seria considerado como falso e ilusório; mundo que confunde e faz acreditar que as sombras são a realidade como ela é.
Se o alicerce do pensamento platônico foi empreendido a partir esse dualismo, como a mímeses seria concebida? Enquanto uma forma inferior, posto que é imitação de coisas sensíveis que, por sua vez, não são ideias verdadeiras. Ou, como colocado pelo próprio filósofo, "algo inferior que se associa a uma coisa inferior para gerar um produto inferior" (A república, $X, 603 b)$. O poeta, o pintor e o escritor não entendem do mundo, pois têm como matéria-prima a sensibilidade: cópia da cópia, aparência da aparência.

Sob a égide hibridizada do cartesianismo com o positivismo, esses dualismos foram intensificados na Modernidade, gerando o que Morin (2014) chamaria de "o grande paradigma do Ocidente". Alargou-se assim a distância entre sujeito/objeto, razão/ emoção, imagem/ pensamento, cultura/natureza e alma/corpo. Através dessa concepção, em que a arte aparece como algo marginal em comparação à ciência, a linguagem dessa e daquela adquirem características próprias; conforme Moreira (2007), tornou-se inconcebível que alguém considerado cientista escrevesse com o mesmo estilo de um poeta, visto que o seu lugar de fala deve atender a parâmetros objetivos e rigorosos. Para muitos, é algo fora de questionamento que o discurso científico deve valer-se de um estilo seco e desinteressante, até mesmo porque a subjetividade seria obstáculo para o bom funcionamento do método. Entretanto, acompanhamos Moreira (2007, p. 146) na pergunta: "Se o objeto da fala, da ciência como da arte, é o mundo do próprio homem, a diferença estando na fala, como pode o homem falar de si mesmo de forma tão dupla, omissa e dissonante"?

Por outro lado, ao acoplar essa lógica aos arranjos produtivos em vigência, nos quais a cultura do utilitarismo é chancelada pela economia de mercado, ações que não trouxerem lucro, uso imediato e/ou não puderem ser mensuradas laboratorialmente serão tidas como inferiores e, logo, desinvestidas pelo Estado e pela própria sociedade civil. Nessa conjuntura, "[...] um martelo valerá mais que uma sinfonia, uma faca mais que um poema, uma chave de fenda mais que um quadro" (Ordine, 2016, p. 12).

Entretanto, tais imposições não impediram que as artes tenham servido como porta de entrada para problematizar determinadas épocas. Lembremos, 
por exemplo, das análises culturais feitas por Marshall Berman junto a Goethe em Tudo que é sólido desmancha no ar, a substituição do fordismo pela acumulação flexível identificada por David Harvey no filme Blade Runner e teorizada em Condição Pós-Moderna e, mais recentemente, a história da desigualdade no capitalismo desenvolvida por Thomas Piketty com o Capital no Século XXI, onde romances de Balzac foram dissecados. São pesquisas que se desenrolam com base na primazia das artes sobre critérios supostamente neutros e objetivos, praticando um "platonismo invertido". Diga-se de passagem, uma perspectiva de trabalho já presente na obra de Nietzsche, em que o lugar atribuído às artes sempre foi mais privilegiado do que o do conhecimento. Não há nada por detrás nem acima das aparências; a essência não substitui a imagem: o artista é poderoso porque pratica uma análise epidérmica; a prova de validação do seu trabalho não será proveniente da lógica nem da ciência, mas da vontade de potência do seu trabalho; a exigência básica para lograr êxito é encontrar eco na vida, passar pelo crivo da existência em ato (Machado, 1999).

Michel Houellebecq não apresenta no prefácio de cada livro o método a partir do qual as ficções serão construídas. Ao contrário de conterrâneos como Sartre e Camus, não conseguimos identificar os posicionamentos filosóficos dos seus personagens. A identidade dos sujeitos em Houllebecq é fluída, cambiável e flutuante, dependendo pragmaticamente das circunstâncias espaciotemporais. As ciências, em especial as humanidades, são vistas com desconfiança ou como incapazes de contribuir para o entendimento do que está acontecendo. Mesmo assim, processos complexos como a globalização, a desindustrialização, as novas tecnologias, a transição demográfica e o aumento dos casos de depressão são analisados criticamente nas suas consequências nefastas. Isso tudo vem me levando a concluir que o método praticado por Houellebecq nos seus escritos se ancora, sub-repticiamente, num certo "platonismo invertido". O que me permite fazer tal deslocamento é o auxílio de entrevistas e palestras realizadas pelo próprio autor.

Em dois diálogos com Juremir Machado da Silva um dos seus tradutores no Brasil - o escritor francês disponibiliza algumas pistas da sua perspectiva de trabalho ou, em outros termos, um convite à "fábrica” metodológica (Houellebecq, 2000, 2002).

Antes de mais nada, Houellebecq (2000) se considera um autor maldito que se tornou famoso; essa autodenominação the impede de pleitear qualquer liderança ou posição de guru de uma geração. Essa marginalidade decorre do fato dele não se enquadrar em nenhum movimento utópico e, ademais, desacreditar qualquer binarismo que apreenda a realidade a partir de divisas como progressistas versus reacionários e/ou esquerda versus direita. Ele argumenta que em meios às transformações culturais e comportamentais arroladas a partir dos anos sessenta e simbolizadas pela "geração de 1968", a sociedade vem mergulhando num caos identitário cuja causa é proveniente do individualismo, do culto ao corpo e da exaltação exagerada das liberdades individuais (Houellebecq, 2000). Alimentado pelo egoísmo dos seus indivíduos, que se principiam pelo prazer a qualquer custo, o mundo que se apresenta no século XXI é patético. Competiria à literatura lançar seus personagens nesses estranhos lugares, registrando suas experiências no âmbito da dor, do vazio, do adoecimento, da aprendizagem dos desgostos.

Embora os aspectos impressionantes presentes nos seus livros deem a ideia de que estaríamos diante de um escritor com alto grau de imaginação, tal impressão seria falsa. Até porque nos deparamos com personagens que não nos são completamente estranhos, com alguns deles poderemos até nos identificar. Seriam gente como a gente? Escutando de Houellebecq as fontes das quais ele se utiliza para o desenvolvimento dos seus protagonistas, a resposta é sim. Afinal, como o próprio coloca,

[...] trabalho por aproximações. Escuto muito as pessoas. Ouço-as com atenção e cuidado, mesmo quando pensam que não estou interessado no que dizem. Com frequência, o que as pessoas me falam reaparece, tal e qual, em meus romances. Talvez se possa chamar-se isso de método de prospecção da realidade por contato direto e informal. Chamo isso simplesmente de ouvir e aproveitar. (Houellebecq, 2002, p. 133).

Por intermédio desse "método de prospecção da realidade", o escritor francês concretiza enredos 
que não seriam nada mais do que retratos fiéis da época em que vivemos sem que, para tanto, precise recorrer a intermediários oriundos da intelectualidade. Escolha deliberada, pois Houellebecq (2002) não só crê que as artes podem prescindir das ciências como essas são incapazes de captar, objetivamente, a complexidade das geografias cotidianas. Com depoimentos transparentes, onde a forma e o conteúdo formam um único elo, as histórias houllebecquianas avançam com uma linguagem seca e direta, sem formalismo nem, tampouco, verborragia. A regra de ouro é "Dar transparência ao invisível por excesso de luz" (Houellebecq, 2002, p. 136). É preciso estar à espreita, atento aos detalhes, absorvendo sensações e observando as paisagens que se apresentam aos sentidos e às categorias perceptivas. Desse modo, veríamos o evidente, o que está na superfície, mas que passava batido diante de calejados olhos crescidos em tempos velozes. É na contracorrente da aceleração que Houllebecq "rumina a próxima história e espia o mundo com os olhos feito os olhos de um peixe morto" (Silva, 2002, p. 132).

Em O mapa e o território, best-seller lançado em 2010 e congratulado com a distinção literária mais cobiçada na França - o prêmio Gouncout -, Houellebecq (2012) exercita o recurso de se inserir na história como um dos personagens coadjuvantes. Descreve-se como um sujeito recluso e conservador, esgotado pelos anos de trabalho necessários para alcançar o reconhecimento do público e da crítica. E que, uma vez no topo, mergulhava no inferno dos ansiolíticos, do alcoolismo, dos alimentos ultraprocessados e da falta de um sentido para seguir em frente. Nesse meio tempo, o protagonista da história (o interlocutor Jed Martin) consegue extrair alguns elementos cruciais para compreendermos sua forma de ler e escrever sobre o mundo. Assim transcorre o diálogo:

É sempre possível, dissera-Ihe Houellebecq ao evocar sua carreira de romancista, fazer anotações, tentar alinhar frases; mas, para nos lançarmos na escrita de um romance, temos que esperar que tudo se torne compacto, irrefutável, esperar a eclosão de um real foco de necessidade. Não cabe a nós a decisão de escrever um livro, acrescentara; um livro, segundo ele, era como um bloco de cimento que pode ou não endurecer, por isso as possibilidades de ação do autor limitam-se a estar presente, esperando, numa inércia angustiante, que o processo dispare automaticamente. (Houellebecq, 2012, p. 190).

Em entrevista dada ao El País, Houellebecq (2015) colocaria que o real foco de necessidade advém da sensação de medo das pessoas, um temor generalizado cuja causa é a incerteza sobre o que vai acontecer. Esse é o sentimento que acaba sendo mola propulsora para os romances, ainda que tal prática desencadeie reações violentas ao seu trabalho. Não por acaso, diga-se de passagem: com uma literatura que capta esse mundo corroído pelo desemprego estrutural, pela obsolescência planejada, pelo consumismo supérfluo, pelos vínculos afetivos temporários, pela corrosão do caráter e pelo bombardeio de informações, que personagens haveríamos de ter?

Ao descrever que tipos de identidade são forjadas num contexto de crise sistêmica, Houellebecq corre o risco de ser carimbado com muitos rótulos, malgrado ele em nenhum momento tenha declarado que seus personagens sejam porta-vozes das suas ideias. Mas como esse argumento é ignorado, Silva (2002) pontua que o ódio à sua pessoa está representado em várias matrizes sociais: os movimentos de esquerda o tem como reacionário e conservador; os de direita, como um terrorista à moral e aos bons costumes; as feministas acusam-no de machista e de menosprezar as mulheres; para os homens, trata-se de uma pessoa frustrada sexualmente; os imigrantes consideram-no um racista da pior estirpe; para os muçulmanos ele já foi considerado inimigo público. Estamos diante de um escritor singular, de difícil timbragem e que parece não estar a serviço de qualquer causa. Seu compromisso é com a tradução em letras da contemporaneidade. Doa a quem doer, custe o que custar. Não se pode culpar a literatura quando ela aparece como um espelho rachado que reflete aquilo nos tornamos.

Ao focar no "temível", o escritor francês sabe que está colocando a mão num vespeiro. Não há espaço para o politicamente correto, para alçar valores ingênuos e fabricados pelo corporativismo publicitário à condição de discursos oficiais. Deveríamos ter vergonha daquilo que somos, da força que fizemos para nos tornamos menos humanos: concorremos conosco e com os outros o tempo todo, em busca 
de metas irrealizáveis, fúteis e que, quando alcançadas, são redefinidas, de modo que a lógica do sistema é um eterno recomeçar do zero. Nesse ínterim, abandonamos aqueles que não contribuem para a manutenção/aceleração do hedonismo, do culto ao consumo e do trabalho em tempo integral: as regras da economia de mercado foram expandidas para as relações afetivas. Porém, e no fundo sabemos que a hora de sermos descartados não irá tardar, inúteis do amanhã, o que aumenta o furor por poder mais. Canibais para si e para os outros, pois. Tudo se torna um permanente cálculo de custo e benefício.

Pela razão de Houellebecq se ocupar dessa perspectiva, perto dele "a maioria dos autores parece se ocupar de literatura infanto-juvenil. De certo modo, ele não faz literatura. Limita-se a pôr as tripas do mundo para fora" (Silva, 2016, p. 21). Essas vísceras têm lugar de procedência definido: o estágio atual do capitalismo, escudado pelo enaltecimento de comportamentos individualistas. Não é possível apreendê-lo pagando tributo a valores ingênuos, transmitindo a falsa noção de que existiria, apesar de eventuais percalços, uma grande marcha universal em direção ao progresso. Ao contrário dos circuitos intelectuais e da esfera universitária, nos quais o comprometimento com o capital simbólico impõe a obrigatoriedade de uma visão "interessada" de mundo, a literatura não deve ser engessada. É com esse critério que Houellebecq tem comprometimento. É o que the permite empreender um estilo radical, distribuindo doses de verdade aos seus leitores e, talvez sem intenção direta, contribuindo para uma das suas máximas: que cada um troque o intelectual preferido por um bom romancista (Houellebecq, 2016).

Mas se nosso autor adota essa perspectiva, é porque nunca desejou ser considerado como um intelectual. Para Houellebecq (2016), um sujeito dessa estirpe pode ser representado como alguém graduado nas mais nobres instituições universitárias e que realiza pesquisas no âmbito das literaturas ou das ciências humanas; essa pessoa dirige coleções importantes na sua área, assume um posicionamento político definido, aparece com frequência em variadas mídias e, ao fazê-lo, procura pautar a discussão, encaminhando as perguntas necessárias. Tem ferramentas para se tornar um profeta, aglutinando ao seu redor seguidores, estudantes e simpatizantes. Ora, a percepção houellebecquiana serve para posicionar todos os lugares em que esse autor não quer estar. Nas suas palavras, "não tenho a mentalidade de um líder. Detesto estabelecer diretivas ou dar ordens" (Houellebecq, 2000, p. 128). Por outro lado, por considerar-se como proprietário de um pensamento livre, anárquico e desgarrado de qualquer idealismo, a própria ideia de se tornar um "papa" fica sem sentido.

Essa discussão foi fomentada pelo próprio autor, em palestra na cidade de Porto Alegre no ciclo Fronteiras do Pensamento, em 2016. O ponto de ligação na fala daquele evento foi o de analisar a trajetória dos "formadores de opinião" franceses durante o século XX, além de colocar em questão as tarefas desses no século que se inicia. Para tanto, dividiu o percurso em três épocas.

A primeira é após a Segunda Guerra Mundial, quando os intelectuais de "direita" estavam desacreditados, abrindo assim espaço para a dominação dos intelectuais "progressistas". O horror ao nazismo não permitia nuanças e ideias fronteiriças. Devido a esse a priori histórico, o caminho estava aberto para Jean-Paul Sartre. Houellebecq (2016) Ihe endereça comentários ácidos: autoproclamado "guru" de uma geração, ele simboliza o início da decadência do pensamento francês: cientificamente, era um ignorante; filosoficamente, seu conhecimento era reducionista e panfletário; em termos de compreensão do mundo, parecia não estar a par do que estava acontecendo; estilisticamente, seu texto era pobre. Merecidamente, foi varrido do establishment a partir dos anos sessenta e, do que fez, não se aproveita hoje praticamente nada. Porém, deixou um legado: o controle do discurso por parte das "esquerdas".

A segunda época se desenvolve na esteira dos eventos de 1968, tendo na linha de frente Foucault, Deleuze, Lacan e Derrida. Por intermédio desses escritores, aconteceu uma oxigenação de forma e conteúdo, com a introdução de conceitos que procuravam se distanciar do marxismo. Ficaram apenas nas boas intenções. Houellebecq (2016) identifica neles uma "verborragia elegíaca e pseudopoética" que parece ter sentido, mas não tem nenhum. Prefere 
considerá-los como charlatões e enganadores, que se engrandeceram às custas da pobreza teórica dos movimentos esquerdistas.

Atualmente, estamos num período singular, em que os intelectuais parecem não ter nada a dizer: não conseguem pensar a realidade para além de binarismos ideológicos e palavras vazias. Houellebecq (2016) dá exemplos. Qualquer sujeito que considere a União Europeia como uma invenção feita por tecnocratas com o objetivo de acelerar o livre mercado, é chamado de reacionário. Já aquele que defende a manutenção de uma identidade nacional, baseada no uso da língua pátria e de certas tradições culturais, é reacionário. Outros que criticam a democracia representativa, hoje dominada pela espetacularização midiática e alimentada pelas bolhas das redes sociais serão, também, reacionários. E para os que suspeitam do lazer de massa agenciado pelo marketing e do turismo parametrizado por experts de comportamento, não haverá outra denominação que não a de... reacionários.

Esse apontamento feito por Houellebecq sinaliza um esgotamento teórico-metodológico também diagnosticado por Maffesoli (2010): tomando por base noções como as de Indivíduo, Bem, Civilização, Justiça, Razão, Economia, Ideal e Progresso, a maioria dos intelectuais se aprisionaram numa mediocridade generalizada que só se justifica por instinto de preservação institucional e simbólica. É o que thes fazem, por um lado, achar que podem falar em nome do Ideal, da Humanidade, da Classe e, por outro lado, dizer para os outros como devem agir. O resultado, escreve Maffesoli (2010, p. 49), é essa "miríade de ensaios, artigos, discursos, tratados eruditos cheios de ideias banais. Produções acomodadas e de um tédio mortal". Não por acaso, nos últimos vinte anos são os escritores que vêm contribuindo para a compreensão da contemporaneidade (Houellebecq, 2016). O motivo é de fácil compreensão: liberados dos "griIhões da esquerda" e, ao mesmo tempo, antipáticos com a intitulada "direita", eles vêm experimentando uma situação inédita: estão livres. Desencantados com teorias circunscritas aos séculos XVIII e XIX, permitem-se examinar a realidade diferentemente do que se examina, vertendo suas criações para a literatura sem a exigência de filtros conceituais. É graças a eles que Michel Houellebecq é otimista sobre o futuro do pensamento.

Por intermédio de um estilo enxuto que, nos termos de João Cabral de Melo Neto, é moldado por uma "faca só lâmina", Houellebecq oferece outros modos de ver e sentir o presente. É impossível ser indiferente aos seus romances. Ele é hábil em lançar seus personagens em situações que representam o que significa ser e estar no mundo nesses dias. Suas narrativas se inserem no domínio da estrutura concreta dessa sociedade infernal que, diria Calvino (1993, p. 71), "já está aqui, na qual vivemos todos os dias, que formamos estando juntos". Esse é o cerne do seu método.

Ao fazer na próxima seção uma descrição panorâmica de alguns textos do autor, gostaria de acrescentar uma pequena tese: a de que os enredos de Houellebecq possuem acentuada carga geográfica, que funcionaria em relação de imanência com a acumulação flexível do capital. A hipótese é que estaríamos tratando de histórias notoriamente espacializadas, em que o acesso à realidade concreta é dado pela estética literária.

\section{0 espaço do presente: peça-chave}

Embora uma obra literária não opere com conceitos, ela adota o critério da verossimilhança, talhando a ficção com elementos substanciados pela intersecção espaço-tempo. Talvez seja por esse motivo que amiúde tenhamos a impressão de que "tomando de empréstimo ao espaço circundante as armas de sua leitura simbólica, rica de significados subjetivos, a literatura acaba por ser uma leitura do mundo mais eficaz que a da geografia e da história" (Moreira, 2007, p. 145).

Parece ser essa a sensação que temos quando mergulhamos no universo de Michel Houellebecq. E esse sentimento deve sua condição de possibilidade ao ciclo de "compreensão do tempo-espaço" caracterizado por Harvey (2012), cujo impacto vem desencadeando transformações dramáticas nas práticas político-econômicas e culturais. Ancoradas na acumulação flexível, processo que veio para ultrapassar o fordismo, elas alcançam crescimento mediante a 
destruição constante de tudo que é produzido, pois a regra do sistema é a criação permanente de novos desejos e necessidades.

No que se refere às relações de trabalho, elas são aceleradas brutalmente, de modo a se adaptarem a uma alta capacidade produtiva, cujo prazo de giro é curto e as tendências devem ser efêmeras. É ingenuidade acreditar que as habilidades adquiridas pelos trabalhadores hoje serão para a "vida toda", que suas respectivas "formações iniciais" serão suficientes para dar conta das mudanças em curso. Num golpe de sorte, certas profissões podem ser recondicionadas, embora mais provável é a maioria delas se tornarem inativas, forçando aqueles que vivem do trabalho a sucessivos recomeços.

Para o espaço, o impacto se dá através da valorização provisória de lugares que possuem certas qualidades na arena da competição global - as chamadas vantagens locacionais relativas. Devido ao vencimento do espaço pela velocidade dos transportes e das tecnologias, o capital derruba as barreiras e desconsidera as distâncias, podendo explorar lucrativamente determinadas características. No entanto, Harvey (2012) acentua que um modelo ancorado na aceleração do tempo de giro impossibilita a previsão da "vida útil" dos lugares, de modo que a única certeza será o abandono deles no futuro. A configuração do desenvolvimento geográfico deve ser, indispensavelmente, desigual.

É por intermédio desse combinado espaço-tempo que a existência do sujeito moderno será definida, pois se "O mundo se forma e o estar é ser no mundo" (Moreira, 2007, p. 157), a discussão desemboca na ontologia, entendida aqui como a relação recíproca dos homens e mulheres com o seu meio e consigo mesmos. E é por meio dessa interação que Michel Houellebecq desvela o que significa "estar aí" na contemporaneidade, examinando experiências individuais, condutas de vida e modos de experimentar o mundo à luz de uma geografia em ato.

Comecemos pelo destaque dado aos efeitos da industrialização, o tema de fundo de $O$ mapa e o território. O enredo em questão delineia os encontros e desencontros do pintor e fotógrafo Jed Martin, artista desconhecido alçado à condição de celebridade milionária após o sucesso de dois projetos seus: uma coleção de fotografias de mapas rodoviários e a série de telas pintadas a óleo que representam profissões em vias de extinção. No primeiro feito, o título da exposição já denota o cerne da proposta: "O mapa é mais interessante que o território" (Houellebecq, 2012, p. 58); com esse termo, Jed Martin sinaliza que a imagem possui maior fascínio do que a realidade em si mesma, atribuindo à representação o valor de verdade do espaço. No que tange aos registros fotográficos de variadas profissões (açougueiro, escritor, lojista, etc.), o termo chave é a beleza de ofícios desprestigiados e/ou dragados pela tecnologia; trabaIhos que iriam "desaparecer em breve, e era importante fixar sua imagem na tela enquanto ainda era tempo" (Houellebecq, 2012, p. 90).

Porém, se as primeiras partes desse livro se centralizam nos efeitos de um consumo em massa capitaneado pela indústria, a desindustrialização em curso também produz suas próprias chagas. Dirigindo pelo interior francês, Jed Martin observa na paisagem as marcas desse processo, que estava materializado nas dezenas de parques industriais abandonados à beira da estrada. Por outro lado, a relação com o seu pai, o arquiteto aposentado Jean-Pierre, é emblemática para o desfecho da narrativa. Rico e bem-sucedido, tratava-se de um homem profundamente infeliz com o resultado da sua obra: hoteis padronizados para a classe média-alta. Profissional engajado em causas progressistas na juventude, abandonou com o sonho de uma "arquitetura socialista" em prol de enriquecimento pessoal; portador de um câncer em estágio avançado, planejava a morte numa enorme residência localizada em bairro anteriormente promissor, agora cercado por criminalidade, prostituição e tráfico de drogas; área corolário do dramático desemprego estrutural, ao qual a alta sociedade parisiense fecha os olhos, mas abre os bolsos: investe em cercas eletrificadas, muros altos, câmeras de vigilância e segurança privada. Consciente desse processo, mas incapaz de domá-lo, resta a Jed Martin afastar-se de Paris em direção ao bucólico interior francês, não sem antes construir sua própria fortaleza, acessível por meio de veículos utilitários esportivos, as chamadas "SUVs".

A organização do espaço agrário também repercute na narrativa dos livros Extensão do domínio da luta 
e Serotonina. Em ambos os romances, tem-se como pano de fundo as causas e os efeitos da modernização da agricultura, à luz do processo de globalização e da subsequente "guerra dos lugares". Como resultado, a produção no espaço rural deve atender a critérios científicos e ser balizada por instrumentos estatísticos e tecnológicos, a fim de incrementar a eficiência e a eficácia. Os Estados, por sua vez, admitem que não podem subsidiar os agricultores e, a um só tempo, protegê-los do confronto com locais que produzem mais e por menos preço; isso os faz transferir para os departamentos e ministérios de agricultura a responsabilidade de modernizar o agronegócio, para torná-lo mais competitivo. Parece uma mudança necessária. As consequências humanas, porém, fogem do controle.

Em Extensão do domínio da luta, Houellebecq (2001) acompanha a jornada de dois técnicos de informática contratados de forma terceirizada pelo Ministério da Agricultura da França para implementar um novo software de aferição da produtividade agrícola. Eles ficarão no meio do fogo cruzado onde estão, em um lado, os coordenadores locais e, no outro, os servidores de médio escalão do governo. Os primeiros são habitantes do interior, típicos moradores interioranos, que praticam a agricultura há séculos e entendem-na em termos tradicionais, de forma menos capitalista e mais rentista. Já os servidores, conscientes da decadência em virtude da concorrência global, creem fielmente que a tecnologia pode combater sintomas econômicos estruturais e, por tais motivos, não hesitam em impor de cima para baixo um novo sistema operacional. O resultado desse embate é patético. Compete aos protagonistas "Nosso heroi" (depressivo e misógino) e Raphael Tisserand (bem-sucedido no trabalho, fracassado nas relações amorosas) circular pelo mundo rural francês sem nenhuma chance de redenção: cobrados em desempenho pela dobradinha empresa/ministério, ignorados pelos agricultores, não agradarão nem esses nem aqueles.

Serotonina, a história mais recente do escritor, descreve a ida sem volta ao inferno emocional de Florent-Claude Labrouste, servidor de carreira do Ministério da Agricultura e lá considerado como um dos melhores especialistas no agronegócio francês.
O fato de ser bem-remunerado e respeitado por seus minuciosos relatórios não o impede de sofrer por insegurança sexual e ansiedade, combatidos através do consumo de produtos luxuosos e da relação com uma mulher fútil e vinte anos mais jovem, que está junto a ele por interesse financeiro (Houellebecq, 2019). Quando Florent-Claude descobre uma gravação pornográfica de alta escatologia e péssimo gosto na qual sua companheira é a estrela, esse acontecimento é a chave para ele mergulhar num estado de depressão profunda, tratada via Captorix, um antidepressivo potente, mas que tem como efeito colateral impotência e falta de libido. Desesperado por um sentido na vida, passa a perambular por hoteis, cafés e restaurantes, à espera de algo bom que nunca chega. E quando resolve visitar um velho amigo no interior, produtor de leite endividado devido aos efeitos do liberalismo comercial, tal deslocamento ratifica o que seus relatórios já sinalizavam: a emergência de camponeses enfurecidos pelo abandono do Estado francês, que vinha abdicando da sua responsabilidade para com a agricultura nacional em prol da União Europeia. Através de uma consultoria dada informalmente à associação leiteira local, Florent-Claude é certeiro: não há esperança. Doravante, o desfecho será impactante, ainda que óbvio: abandonados à própria sorte pelo Estado, resta-Ihes insurgir contra ele no âmbito do espaço, com o fechamento de importantes estradas. Tragédia anunciada.

Com Plataforma e Partículas elementares, a visão houellebecquiana é endereçada ao turismo contemporâneo. Ela acompanha as características por meio das quais o espaço é experimentado hoje, isto é, como uma categoria na qual a distância deve ser constantemente suprimida. Nesse sentido, o mercado turístico investe na compressão espaço-temporal de maneira semelhante ao consumo de objetos e outros dispositivos: deve-se ter tudo, desde que por pouco tempo; a concentração se dirige provisoriamente a elementos que devem ser consumidos, mas que o sejam com a curto prazo. A expectativa substitui a realização: o esforço e a compra são mais prazerosos do que o usufruto da propriedade adquirida. Nessa lógica, "viajar esperançosamente é na vida do consumidor muito mais agradável que chegar" (Bauman, 1999, p. 93). O viajante se transforma num globetrotter, andarilho que procura diversão e satis- 
fação em viagens internacionais; acostuma-se com a sensação de ser bem recebido numa rede de serviços projetada pelas agências, que estabelecessem suas ações com a meta de que a mercadoria vendida deve atender aos sonhos e aos desejos pessoais. Cada viagem tem que ser, forçosamente, uma aventura. Mas, por outro lado, através da derrubada das fronteiras à livre circulação do dinheiro, cria-se uma confortável sensação de sinal verde para o globetrotter, que pode sentir-se familiarizado por locais e pessoais que conheceu recentemente. O turismo ideal deve, com efeito, oportunizar subsídios para que os viajantes se transformem em "caçadores de emoções e colecionadores de experiências" (Bauman, 1999, p. 102).

Porém, ao contrapor o globetrotter ao "vagabundo" pelo grau de frustação, que é zero no primeiro e máximo no segundo, Zygmunt Bauman ignora o fato de que também o excursionista "modelo" é um consumidor insatisfeito. Mas essa expectativa fracassada não passa despercebida pelo radar de Michel Houellebecq. Nos seus livros, as viagens são entendidas como acontecimentos tediosos e previsíveis, que produzem no turista sorrisos amarelos; enquadrado por roteiros agendados por profissionais que o veem como um cliente ingênuo, não deve haver naturalidade nem tempo disponível para que se possa contemplar calmamente as paisagens, pois o entretenimento é delineado tendo em vista o lucro permanente dos fornecedores de serviços. O olhar é dirigido, as interpretações são determinadas e azeitadas com falsas estórias, que atribuem aos lugares identidades artificiais, plena de traços mercadológicos. Assim, não há surpresa nem encantamento, um turismo que funciona à maneira de parque de diversões infantil, no qual o desfecho das atrações pode ser avistado de antemão.

Sob esse pano de fundo, Plataforma conta a história de sujeitos a serviço de uma agência de turismo internacional que adquire o controle de uma rede de resorts cujo investimento, aparentemente promissor, não vem apresentando lucros. O grupo majoritário de acionistas, ao ouvir a consultoria de um especialista nominado por Houellebecq (2018) como "sociólogo do comportamento", tem a seguinte resposta para o fracasso: as pessoas hoje querem que suas viagens sejam uma realização pessoal, desde que haja compromisso ético; abdicando do egoísmo, almejam partilhar uma perspectiva de solidariedade. Desse modo, ao investir em atrações que incluíam atividades esportivas, caminhadas guiadas, esportes em contato com a natureza, interação com animais, visitas à comunidade local, sessões de yoga/ pilates e ampla oferta gastronômica, acreditava-se que a decadência seria estancada. Ledo engano: a monotonia se mantinha, impedindo que houvesse fidelidade entre os clientes, que não retornavam aos estabelecimentos. No entanto, quando os gestores Valérie e Jean-Yves percebem que a chave para capturar consumidores hedonistas e narcisistas reside no culto ao prazer, o turismo sexual se transforma na solução óbvia. Oferecendo corpos jovens, atraentes e sexualmente habilidosos a homens e mulheres melancólicos, endinheirados e onanistas de meia-idade, o negócio rapidamente se torna lucrativo. Todavia, esse empreendimento ao que tudo indica frutífero cobrará um alto preço à vida dos personagens.

Partículas elementares tem como enredo a crueldade subjacente à geração nascida em meio aos eventos culturais da década de 1970. Crentes de que seria possível viver à margem da economia, dos costumes, da moral, da religião e da educação vigente e, concomitantemente, ingênuos quanto aos danos irreversíveis que um comportamento "libertário" poderia causar, os personagens projetados por Houellebecq (2008) recebem uma passagem só de ida ao inferno de uma vida desprovida de télos. Um dos pontos de parada está localizado em comunidades hippies localizadas junto à natureza, em áreas distantes dos espaços urbanos. Idealizadas como refúgios aos impactos ambientais, precursoras de uma vida sustentável e tendo como bandeira maior a luta pela sexualidade, revelam-se experiências fracassadas em termos administrativos e econômicos. Para sobreviver, efetuarão uma contundente transição, ou seja, a de lugares alternativos e baluartes da contracultura a símbolos do neoliberalismo. A rotina é preenchida com convenções, treinamentos específicos de timbre corporativo, palestras com charlatões e "guias de conduta", simulações em campo que estimulam melhor comunicação, criatividade, trabalho em equipe, liderança, cooperação, busca de metas, engajamento, superação de desafios, entre outros processos de teor semelhante. Em outras palavras, eventos 
simuladores da realidade, encaixados às supostas dinâmicas vivenciadas pelas empresas, mas que insistem em manter uma roupagem libertária, como se lá se pudesse resistir aos efeitos maléficos do status quo. Pura bobagem, registrada brilhantemente por Michel Houellebecq. Não há nada de novo sob o sol nesses espaços que se pretendiam transgressores, mas que nada mais são do que acampamentos credenciados pelo sistema e frequentados por indivíduos estafados de trabalho, frustrados sexualmente, traídos pela esperança de uma vida gozada exponencialmente até o final.

Finalmente, por intermédio de observações da demografia europeia contemporânea, Houellebecq (2015) permitiu-se fazer futurologia em Submissão. Tomando por base o caldeirão de conflitos em que se transformou a França do século XXI, o escritor acentua como os valores iluministas estariam em xeque na Pós-Modernidade. Devido ao deslocamento dos parques industriais para países que oferecem benefícios fiscais e mão de obra-barata e não-sindicalizada, os postos de trabalho nesse setor são extintos; com a competitividade dos países substancialmente agroexportadores, o meio rural francês cede aos empréstimos do capital especulativo para se manter no jogo, mas sem sucesso; a intensificação dos fluxos migratórios, paralela a uma inédita multiculturalização, assume a dianteira dos vínculos empregatícios de baixo prestígio por parte dos imigrantes; nessa conjuntura de incerteza, em que o estado de crise não é a exceção, e sim o normal, a guinada em direção a fundamentalismos religiosos e a movimentos xenófobos é inevitável. A França chega às eleições presidenciais de 2022 numa encruzilhada: os partidos de esquerda não têm chance alguma, enquanto a extrema-direita está a um passo do poder. Apenas uma peculiar coalização política pode interromper esse processo: a união da centro-esquerda com uma grande frente islâmica, representada pela figura do muçulmano Mohammed Ben Abbes.

O estranho encontro dos ideários socialistas com a Fraternidade Muçulmana encontra na personalidade moderada e aberta ao diálogo de Ben Abbes uma terceira via na política francesa. Eleito com confortável margem de votos sobre a extrema-direita, esse habilidoso político se coloca na contracorrente do anar- cocapitalismo, surpreendendo os analistas. Mas com o bônus vem o ônus, como narrado pelo protagonista François, professor de literatura da Sorbonne: o islamismo assume o controle do sistema educacional francês e, a um só tempo, exclui as mulheres do mercado de trabalho, liberando-as para tarefas domésticas mediante atraente abono financeiro. Haverá resistência? Da parte dos intelectuais acadêmicos, seguramente não. 0 próprio François, ao 1) ter seu salário quadruplicado pela injeção de petrodólares, 2) ser promovido na agora Universidade Islâmica de Paris-Sorbonne; 3) receber um casamento arranjado com quatro esposas; rapidamente abandona seus ideais, conformando apaticamente à nova era. As vozes insurgentes foram caladas às custas de dinheiro e prestígio - e talvez nem tenha custado tão caro assim.

\section{Desfecho: Michel Houellebecq e a condição humana}

Ao não se pretender científica nem ter que pagar tributo a algum estatuto de verdade, a literatura pode desenrolar-se livremente, extraindo da realidade cotidiana ações, percepções e objetos que não precisam passar pelo crivo da análise conceitual. 0 escritor é um artista pelo simples fato de que pode prescindir nas suas obras de ideias e teorias, centrando-se ao invés disso nos sentimentos da vida que lhe parecem fundamentais. Ele resiste aos domínios restritos da linguagem; sabe que, uma vez enclausurado, não será autor. Entretanto, o fato de não ser um acadêmico nem possuir garantias de alcançar postos intelectuais não suprime uma questão importante: o escritor não está isolado. Vale-se de signos provenientes da cultura, da economia, da sociedade, das religiões, da política. De fragmentos em fragmentos, manipula a realidade ao seu favor, aceitando como única regra o atendimento a critérios estilísticos, próprios das melhores ficções. Poderíamos aceitar a afirmação de que os bons escritores são, sub-repticiamente, transgressores?

Juízos à parte, decerto Michel Houellebecq é um transgressor. Não faz concessões, não pede auxílio às "vacas sagradas" do pensamento. Não explica, não teoriza. Mas não inventa: o traço transversal aos seus 
enredos, o fio condutor que os faz tão marcantes, é positivado pela apreensão dos processos absurdos que são parte disso que chamamos de contemporaneidade. Como vimos, é uma questão de geografia: com o fito de acelerar o tempo de giro do capital, o espaço vem sendo capturado pelos interesses viscerais de uma acumulação flexível, para a qual interessa apenas cálculos de eficiência e eficácia. Os Estados, por seu turno, aderem ao discurso da inevitabilidade da globalização e, voluntariamente, contribuem para o colapso das barreiras espaciais, aceitando a crença de que um mercado livre e sem limites - azeitado pelo desenvolvimento tecnológico - é a resposta final para o progresso e o desenvolvimento. Para os qualificados, esse mantra vem a calhar: a velocidade dos investimentos e a conexão instantânea entre os lugares lhes favorece. Para os pobres, a crença nas oportunidades alimentada pelo discurso do empreendedorismo os mantém sob rédea de curta, à espera do sucesso que virá através do trabalho, do esforço, do investimento contínuo em capital humano.

O mérito houellebecquiano é colocar em alto relevo as mazelas desses movimentos, tanto para os bem quanto para os mal-aventurados. Desigualmente correspondidos pelas benesses da economia de mercado, oscilando entre vencedores e perdedores, tratam-se de sujeitos que foram ensinados a acreditar que podem ter tudo, que são livres para gozar materialmente da vida o tempo que quiserem. Foram subjetivados por uma ética neoliberal de individualismo intenso, custe o que custar e custe a quem custar. As consequências são sombrias: neurose, depressão e ansiedade, tratadas com pílulas de consumo e busca de prazer exacerbado.

Michel Houellebecq oferece uma escrita enxuta para repensarmos a globalização e os seus efeitos no tempo e no espaço da vida corrente. Por meio de enredos que acoplam acontecimentos como o turismo, a revolução agrícola e os fluxos migratórios, sinaliza críticas ao duvidoso projeto neoliberal, refutando e relativizando a liberdade transcendente que vem emergindo nas últimas décadas: ela é própria ao consumo, inadequada à convivência cidadã, imprópria para a experiência coletiva. Pagaremos o preço da instantânea aderência a esses valores. As faturas já estão chegando.

\section{Referências}

Bauman, Z. (1999). Globalização: as consequências humanas. Rio de Janeiro: Zahar, 1999.

Calvino, I. (1990). Seis propostas para o próximo milênio: lições americanas. São Paulo: Companhia das Letras.

Calvino, I. (1993). As cidades invisíveis. São Paulo: Companhia das Letras.

Harvey, D. (2012). Condição pós-moderna: uma pesquisa sobre as origens da mudança cultural. São Paulo: Edições Loyola.

Houellebecq, M. (2000). Contraponto: Michel Houellebecq. Entrevista concedida a Juremir Machado da Silva. Revista FAMECOS, 7(12), 127-130.

Houellebecq, M. (2001). Extensão do domínio da luta. Porto Alegre: Editora Sulina.

Houellebecq, M. (2002). O romance como arte da provocação. Entrevista concedida a Juremir Machado da Silva. Revista FAMECOS, 9(18), 131-136.

Houellebecq, M. (2008). Partículas elementares. Porto Alegre: Editora Sulina.

Houellebecq, M. (2012). O mapa e o território. Rio de Janeiro: Record.

Houellebecq, M. (2015). Submissão. Rio de Janeiro: Objetiva.

Houellebecq, M. (2015, 8 de dezembro). "'La islamofobia no es um tipo de racismo". Entrevista concedida a Sylvain Bourmeau. El País Paris. Recuperado de: <https://elpais.com/ cultura/2015/01/07/actualidad/142066 4633694213. html>.

Houellebecq, M. (2016, 19 de novembro). Os intelectuais franceses no começo do século XXI. Correio do Povo. Recuperado de: https://www.correiodopovo.com.br/blogs/juremirmachado/caderno-de-s\%C3\%A1bado-a-fala-bomba-de-michel-houellebecq-1.574.

Houellebecq, M. (2018). Plataforma. Rio de Janeiro: Alfaguara.

Houellebecq, M. (2019). Serotonina. Rio de Janeiro: Alfaguara.

Machado, R. (1999). Nietzsche e a verdade. São Paulo: Paz e Terra.

Maffesoli, M. (2010). Saturação. São Paulo: Iluminuras.

Moreira, R. (2007). Pensar e ser em geografia: ensaios de 
história, epistemologia e ontologia do espaço geográfico. São Paulo: Contexto.

Morin, E. (2014). Meus filósofos. Porto Alegre: Sulina.

Ordine, N. (2016). A utilidade do inútil: um manifesto. Rio de Janeiro: Zahar.

Platão. (1997). A República. Lisboa: Fundação Calouste Gulbenkian.
Silva, J. M. (2002). O romance como arte da provocação. Revista FAMECOS, 9(18), v. 9, 131-136.

Silva, J. M. (2016). O escritor insubmisso. In THOMÉ, L.; MASTALIR, M. (Orgs), Michel Houellebecq: a grande virada. Porto Alegre: Fronteiras do Pensamento. 